\title{
Prospects of nanotechnology for detection of water borne pathogen
}

\author{
Pratima R. Solanki \\ Special Centre for Nanosciences, Jawaharlal Nehru University, \\ New Delhi-110067, India \\ Email: pratimarsolanki@gmail.com; partima@mail.jnu.ac.in
}

In recent scenarios, the development of nanotechnology with novel size and shape dependent properties has shown remarkable potential for fabrication of devices like biosensor for environmental and biomedical applications. These nanostructured materials form an interface with biomolecules, cell-lines, microorganisms etc that creates a channel for fast communication in nanoscale devices that can be utilized for diverse biomedical applications including biosensors, drug delivery, hyperthermia treatment, cell separation etc. ${ }^{1}$ In this context, we have synthesized different nanostructured materials including iron oxide, zirconium oxide, nickel oxide and their composites with biopolymers like gelatin and chitosan. ${ }^{2-5}$ These functionalized nanostructured materials have been utilized for detection of water borne pathogens.

Water borne pathogen can cause severe infectious disease including diarrhea, gastrointestinal infection and systematic illnesses. Thus, it is important to monitor these pathogens in real samples to minimize these types of diseases. So immunosensing platform has been fabricated using different nanostructure materials and these deposited onto indium-tin-oxide (ITO) coated glass substrate. These materials provide a suitable environment for immobilization of specific biorecognition elements (antibodies) for detection of Vibrio cholerae (Vc) utilizing electrochemical technique. It has been found that these nanoparticles provide the improved biosensing properties including sensitivity, selectivity and detection range for detection of pathogens. Figure 1 shows the stepwise fabrication of the sandwich electrode based on the $\mathrm{CH}-\mathrm{NiO} / \mathrm{ITO}$ electrode by the functionalization of BSA and $\mathrm{Ab}-V_{c}$ onto the $\mathrm{CH}-\mathrm{NiO}$ surface for the detection of $V_{c}$ concentration. ${ }^{4}$ For the confirmation of interaction of $V c$ onto $\mathrm{BSA} / \mathrm{Ab}-\mathrm{Vc} / \mathrm{CH}-$ $\mathrm{NiO} / \mathrm{ITO}$, the secondary labelled antibodies $\left(\mathrm{HRP}-\mathrm{Ab}-V_{c}\right)$ are specific to the other epitopes of $V c$, which do not interact with primary antibodies. The change in the electrochemical response of the $\mathrm{HRP}-\mathrm{Ab}-V c / \quad V c / \mathrm{BSA} / \mathrm{Ab}-$ $\mathrm{Vc} / \mathrm{CH}-\mathrm{NiO} / \mathrm{ITO}$ immune-electrode was monitored as a function of $\mathrm{H}_{2} \mathrm{O}_{2}$ concentration using electrochemical as well as optical techniques. This $\mathrm{BSA} / \mathrm{Ab}-\mathrm{Vc} / \mathrm{CH}-\mathrm{NiO} / \mathrm{ITO}$ immunoelectrode provides an excellent detection range of 20-700 $\mathrm{ng} \mathrm{mL}^{-1}$, a low detection limit of $0.108 \mathrm{ng} \mathrm{mL}^{-1}$ and a sensitivity of $0.644 \mathrm{~mA} \mathrm{ng}$ $\mathrm{mL}^{-1} \mathrm{~cm}^{-2}$. The electrochemical based HRP-Ab$V c / V c / \mathrm{BSA} / \mathrm{Ab}-V c / \mathrm{CH}-\mathrm{NiO} / \quad$ ITO sandwich immunoelectrode exhibits a higher sensitivity of $2.95 \mathrm{~mA} \mathrm{mM} \mathrm{mL}^{-1} \mathrm{~cm}^{-2}$ and a $K_{\mathrm{m}}$ value of 19.96 $\mathrm{mM}$. However, the optical based HRP-Ab$V c / V c / \mathrm{BSA} / \mathrm{Ab}-V c / \mathrm{CH}-\mathrm{NiO} / \quad \mathrm{ITO}$ sandwich immune-electrode reveals a sensitivity of $0.064 \mathrm{~A}$ $\mathrm{mM}^{-1} \mathrm{~cm}^{-2}$ with a low $\mathrm{K}_{\mathrm{m}}$ value of $1.0 \mathrm{mM}$.

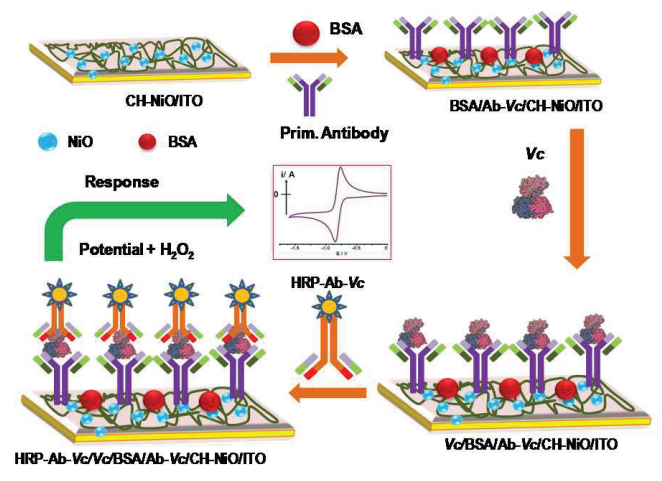

Figure 1: The preparation of the HRP-Ab$V c / V c / \mathrm{BSA} / \mathrm{Ab}-V c / \mathrm{CH}-\mathrm{NiO} / \mathrm{ITO}$ immunoelectrode

\section{References}

1. P.R. Solanki, A. Kaushik, V.V. Agrawal, B.D. Malhotra, NPG Asia Mater. 3 (2011) 17.

2. A. Sharma, D. Baral, K. Rawat, P.R. Solanki, H.B. Bohidar. Nanotech.26 (2015) 175302 (10pp).

3. A. Sharma, D. Baral, H.B. Bohidar, P.R. Solanki, Chemico-Biological Interactions 238 (2015) 129-137. 4.P.R. Solanki, M.K.Patel, Md. A.Ali, B.D. Malhotra; J. Mater. Chem. B, 2015,3, 6698.

5. Y. Bagbi, A.Sharma, H.B. Bohidar, P.R. Solanki; International Journal of Biological Macromolecules 82 (2016) 480-487. 